2011

\title{
Book Review: Tight Fists or Open Hands: Wealth and Poverty in Old Testament Law
}

Roger S. Nam

George Fox University, rnam@georgefox.edu

Follow this and additional works at: https://digitalcommons.georgefox.edu/gfes

Part of the Biblical Studies Commons, and the Christianity Commons

\section{Recommended Citation}

Nam, Roger S., "Book Review: Tight Fists or Open Hands: Wealth and Poverty in Old Testament Law" (2011). Faculty Publications Portland Seminary. 119.

https://digitalcommons.georgefox.edu/gfes/119 


\section{Tight Fists or Open Hands: Wealth and Poverty in Old Testament Law}

by David L. Baker

Eerdmans, Grand Rapids, 2009. 435 pp. \$36.00. ISBN 978-0-

8028-6283-9.

DAVID BAKER FILLS A LACUNA in scholarship with this theological interpretation of wealth and poverty in OT law. Under thematic categories, such as property rights and just lawsuits, Baker outlines the pertinent passages from biblical texts within the context of ancient Near Eastern legal collections. After a whirlwind survey, Baker acknowledges some commonalities between biblical and ancient law regarding economic concerns. But he emphasizes that the biblical law codes ultimately derive from the covenantal relationship with YHWH. Thus, biblical law collectively attests to higher standards of economic ethics than its ancient Near Eastern counterparts.

Baker's approach is largely both synchronic and inductive. Throughout, Baker includes large excerpts of ancient law, allowing readers the freedom of discovery. Such an approach proves effective in two ways. First, for familiar biblical laws (e.g., tithing), the parallel ancient Near Eastern examples force readers to challenge any interpretations that may arise from Christian orthodoxy, rather than biblical understanding. Second, for unfamiliar laws (e.g., unauthorized grazing), parallel texts provide background for understanding the cryptic legal prescriptions.

But in the attempt to cover a wide range of biblical and extra-biblical material, Baker does not adequately deal with several methodological issues. For example, the synchronic approach disregards the valid chronological concerns over the literary relationship between the various biblical and non-biblical law codes. In addition, Baker neglects to outline explicitly his theoretical presuppositions on the nature of the economy of the biblical world. As a result, these unstated assumptions vary throughout the book a his language implies capitalism ("current market value," p. 77), substantivism (declaring no significant money markets, p. 262) and even Marxism (wholesale adoption of the three-tiered stratification of Old Babylonia, p. 111). Such criticisms are understandable in light of the stated intent of the book to provide a deliberately wide overview of biblical law pertaining to wealth and poverty to aid in the discernment of theological and ethical implications for Christian community — an aim, which Baker suitably accomplishes in this useful volume.

ROGER S. NAM

GEORGE FOX UNIVERSITY

PORTLAND, OREGON 